УДК 339.92:656.2(477)

\title{
УДОСКОНАЛЕННЯ МЕХАНІЗМІВ ДЕРЖАВНОГО УПРАВЛІННЯ РОЗВИТКОМ ЗАЛІЗНИЧНОЇ ГАЛУЗІ УКРАЇНИ У СВРОІНТЕГРАЦЙНОМУ ВЕКТОРІ
}

\author{
Дикань В.Л., д.е.н., професор, \\ Островерх Г.Є., аспірант (УкрДУЗТ)
}

В статті обтрунтовано та розроблено науково-методичні та практичні рекомендації щзодо удосконалення механізму державного управління розвитком залізничної галузі в умовах структурного реформування залізничного транспорту у забезпеченні евроінтеграчійного вектору формування конкурентного середовища. Розроблено підхід щудо реалізащії механізму державного управління розвитком залізничної галузі Украӥни з визначенням основних иілей, методів та результатів реалізачії для підвищення конкурентоспроможності залізничної галузі в умовах євроінтеграційних прочесів.

Ключевые слова: державне управління, залізничний транспорт, євроінтеграція, механізми забезпечення, розвиток.

\section{СОВЕРШЕНСТВОВАНИЯ МЕХАНИЗМОВ ГОСУДАРСТВЕННОГО УПРАВЛЕНИЯ РАЗВИТИЯМ ЖЕЛЕЗНОДОРОЖНОЙ ОТРАСЛИ УКРАИНЫ В ЕВРОИНТЕГРАЦИОННОМ ВЕКТОРЕ}

\author{
Дикань В.Л., о.э.н., профессор, \\ Островерх А.Е., аспирант (УкрГУЖТ)
}

В статье обоснованны и разработаные научно-методические и практические рекомендаций по совершенствованию механизма государственного управления развитием железнодорожной отрусли в условиях структурного реформирования железнодорожного транспорта в обеспечении евроинтеграчионного вектора формирования конкурентной среды. Подход к реализачии механизма государственного управления развитием железнодорожной отрасли Украины с определением основных, обобщенных автором, целей, методов и результатов реализачии для повышения конкурентоспособности железнодорожной отрасли в условиях интеграционных прочессов.

Ключевые слова: государственное управление, железнодорожный транспорт, евроинтеграция, механизмы обеспечения, развитие. 


\title{
IMPROVEMENT OF MECHANISMS OF STATE MANAGEMENT OF DEVELOPMENTS OF THE RAILWAY INDUSTRY OF UKRAINE IN THE EURO-INTEGRATION VECTOR
}

\author{
Dikan V., doctor of economic sciences, professor, \\ Ostroverkh H., graduate student (USURT)
}

The article, the substantiation, deepening and development of scientific and methodological and practical recommendations for improving the mechanism of state governance for the development of the railway industry in the conditions of structural reform of rail transport in providing the European integration vector for the formation of a competitive environment. the approach to implementation of the mechanism of state management of the development of the railway industry of Ukraine with the definition of the main, generalized by the author, goals, methods and results of implementation for increasing competitiveness ozhnosti railway industry in terms of European integration processes.

The scientific and methodical approach to the reform of the railway industry of Ukraine on the basis of generalization of strategic directions of the reformation of the railway transport of Ukraine in accordance with the norms of the European Union (the formation of a vertically integrated system of economic management of rail transport, the introduction of state support for passenger transport and liquidation of their financing at the expense of revenues from other activities of railways, improvement of work of technical, border and port railway stations, has been improved the system of evaluation of economic activity in the field of railway transport, improvement of the nomenclature of expenses for economic activity in the field of railway transport, improvement of the process of management of transportation with the use of the latest information technologies, bringing railway transport standards in line with the requirements of the EU) for the effective realization of the directions of public administration of this branch and acceleration Integration of the railway industry of Ukraine.

Key words: public administration, development, railway transport, eurointegration, mechanisms of provision, development.

Постановка проблеми та їі зв'язки 3 науковими чи практичними завданнями. Стабільність розвитку національної економіки залежить від ступеня розвитку кожної з іï галузей та інфраструктурних елементів. Свропейська інтеграція є одним з основних пріоритетів української державної політики. Розвиток залізничної галузі країни $\epsilon$ передумовою для стабільного розвитку та підйому економіки нашої держави, посилення їі конкурентоспроможності, розширення зв'язків між підприємствами та захисту економічних інтересів країни, розширення зовнішньоекономічної діяльності у забезпеченні евроінтеграційного вектору розвитку України.

\section{(1)} оому числі залізничної галузі, все ще не відповідає стандартам, директивам, регламентам, нормам i вимогам Європейського Союзу (СС), відзначається суттєвим відставанням щодо законодавчої та нормативно-технічної бази, інфраструктури, якості тягового рухомого складу, обладнання, спектру i якості сервісних послуг.

Актуальність обраної теми обумовлена необхідністю реформування залізничної галузі України в умовах євроінтеграційних процесів, удосконалення та пошуку механізмів державного управління розвитком залізничної галузі, змінами управління в діяльності 
підприємств залізничного транспорту України.

Формування на залізничному транспорті ринкових відносин і конкурентного середовища потребує прийняття принципових рішень на державному рівні щодо удосконалення структури, методів та принципів державного управління залізничною галуззю.

Аналіз досліджень і публікацій Суттєвий внесок у теоретичне обгрунтування принципів формування механізмів державного управління різних галузей економіки, закономірностей функціонування залізничного сектору, нормативно-правового забезпечення залізничної галузі, проблем і перспектив державного регулювання залізничного транспорту зробили вчені: Ю. Кіндзерський, В. Дикань, М. Кизим, В. Ляшенко, Р. Шепетько, М. Якубовський, Г. Ейтутіс, Н. Якименко, Ю. Бараш, О. Кірдіна, I. Токмакова та інші [1-13].

у своїх дослідженнях вони обгрунтували напрями інтеграційних процесів транспортної системи України до Європейського Союзу на сучасному етапі розвитку залізничної галузі.

Незважаючи на великий обсяг наукових розробок теоретичного та практичного характеру у сфері державного управління залізничною галуззю України, потребують подальшої уваги вирішення ключових проблем державного управління залізничним транспортом в умовах реформування галузі та забезпечення євроінтеграційних процесів.

Мета статті полягає у досліджені механізмів, що застосовуються при реалізації євроінтеграційної політики, та з'ясовані основні проблеми функціонування механізмів реалізації євроінтеграційної політики України в сучасних умовах.

Викладення основного матеріалу. Незважаючи на специфіку принципів функціонування та напрямків розвитку залізничної галузі в залежності від сформованих національних реалій економічної та соціальної сфер, можна виділити ключові особливості, характерні для залізничного транспорту в цілому i актуальні в рамках організації управління галуззю: взаємозалежність і взаємний вплив стану рухомого складу та інфраструктури; значуща роль державного фінансування для розвитку інфраструктури та регіональних пасажирських перевезень; конкуренція між пасажиро і вантажоперевезеннями по одній інфраструктурі; різна характеристика вантажних і пасажирських поїздів; серйозні негативні наслідки на безпеку при відмовах і несправності.

На сьогодні залізниці України стоять на порозі корінних структурних перетворень, які обумовлені необхідністю формування на залізничному транспорті ринкових відносин і конкурентного середовища. На даний момент вже усі держави Європи та країн СНД, за виключенням України, завершили процеси структурних реформ на залізничному транспорті.

Проблемами, які стримують подальший розвиток залізничного транспорту в Україні є:

1 недосконалість нормативноправових актів, що регулюють діяльність залізничного транспорту та невідповідність організаційної структури залізничного транспорту тенденціям розвитку ринкової економіки України;

2 наявність перехресного субсидування збиткових пасажирських перевезень за рахунок вантажних;

3 недостатня фінансова прозорість діяльності залізничної галузі; низький рівень конкуренції на ринку залізничних перевезень [14].

Окрім внутрішніх проблем, які мають бути вирішені в ході реформування, також $є$ і подолання певного відставання у розвитку українських залізниць від залізниць країн Євросоюзу та Росії, які сьогодні знаходяться на різних стадіях процесу реформування, але при цьому суттєво випереджають залізниці України. 
Відсутність безумовної прямої залежності між формою власності залізниць i економічними або якісними показниками їх роботи. 3 урахуванням особливостей соціально-економічного розвитку України, а також, підсумовуючи світовий досвід, можемо сказати, що існує ряд особливостей, які специфічно виділяють ПАТ «Укрзалізницю». В Україні відсутня головна безпосередня причина, що спонукала багато країн шукати вихід у реформуванні залізничного транспорту, конкуренція інших видів транспорту i, перш за все, автомобільного, яка призвела до серйозного скорочення перевезень на залізниці. Водночас, є i незаперечний аргумент на користь реформи - в нинішніх умовах подальший розвиток українських залізниць без реформування - неможливий.

3 одного боку, саме на державних залізницях $є$ умови для створення та впровадження нових технологій, таких як високошвидкісні поїзди, розробка яких, як i будівництво спеціалізованих ліній, були б неможливі без наявності відповідної науково-дослідної бази, а також без державного фінансування. 3 іншого, приватні підприємства, що працюють на концесійній основі, як правило, надають послуги більш високого рівня за прийнятними тарифами.

Дані таблиці 1 свідчать про велику різноманітність видів власності в системах залізничного транспорту європейських країни.

Табличя 1

Види власності та використання мережі на залізничному транспорті краӥн Свропи

\begin{tabular}{|c|c|c|c|}
\hline \multirow[t]{2}{*}{ Країна } & \multirow{2}{*}{$\begin{array}{c}\text { Державна } \\
\text { власність на } \\
\text { інфраструктуру } \\
\text { залізниць }\end{array}$} & \multicolumn{2}{|c|}{$\begin{array}{c}\text { Експлуатація залізниць незалежними } \\
\text { компаніями }\end{array}$} \\
\hline & & Державними & Приватними \\
\hline Швейцарія & $\epsilon$ & $\epsilon$ & $\mathrm{Hi}$ \\
\hline Японія & $\mathrm{Hi}$ & $\mathrm{Hi}$ & $\epsilon$ \\
\hline Австрія & $\epsilon$ & $\mathrm{Hi}$ & $\mathrm{Hi}$ \\
\hline Німеччина & $\epsilon$ & $\mathrm{Hi}$ & $\epsilon$ \\
\hline Люксембург & $\epsilon$ & $\mathrm{Hi}$ & $\mathrm{Hi}$ \\
\hline Бельгія & $\mathrm{E}$ & $\epsilon$ & $\epsilon$ \\
\hline Нідерланди & $\epsilon$ & $\mathrm{Hi}$ & $\epsilon$ \\
\hline Данія & $\epsilon$ & $\epsilon$ & $\epsilon$ \\
\hline Італія & $\epsilon$ & $\mathrm{Hi}$ & $\epsilon$ \\
\hline Франція & $\epsilon$ & $\mathrm{Hi}$ & $\epsilon$ \\
\hline Великобританія & $\mathrm{Hi}$ & $\mathrm{Hi}$ & $\epsilon$ \\
\hline Швеція & $\epsilon$ & $\epsilon$ & $\mathrm{Hi}$ \\
\hline Норвегія & & $\mathrm{Hi}$ & $\mathrm{Hi}$ \\
\hline
\end{tabular}

Другий висновок, що випливає 3 аналізу зарубіжної практики функціонування та реформування залізниць, складається у реалізації різних форм технічних i економічних взаємозв'язків, існування відокремлених залізниць на регіональному та місцевому рівнях. Це відкриває великі можливості в подоланні одноманітності в експлуатації, а також розвитку залізниць по шляху більшої диференціації рівнів обслуговування.
Третій висновок полягає у високій ефективності великих вертикальноінтегрованих систем на транспорті.

Механізм реформування й розвитку залізничного транспорту в контексті реалізації структурних реформ у галузі почався з відновлення економіки України після тривалої економічної кризи, активізація зовнішньої торгівлі внаслідок поступового відкриття європейських товарних ринків, а також загальносвітова 
тенденція до підвищення мобільності населення вимагають стабільної та ефективної роботи залізничного транспорту.

Транспортна політика держави стає інструментом реалізації національних інтересів, що дозволяє розглядати ऑiі як елемент, здатний впливати не тільки на ефективність економічного розвитку, але i на передумови розширення співпраці держав і зміцнення інтеграційних процесів. Так інтеграція України в світову економіку і диверсифікація зовнішньої торгівлі вимагають модернізації залізничної інфраструктури, реалізації потенціалу України як транзитної держави, підвищення взаємодії та конкурентоспроможності вітчизняних перевізників i розвиток експорту транспортних послуг.

Результатом структурної реформи ПАТ «Укрзалізниця» повинно стати організаційне відокремлення інфраструктури та національного перевізника всередині холдингової структури, як це передбачено актами законодавства ЄС в сфері залізничного транспорту. Розмежування державних i господарських функцій, розподіл монопольних i конкурентних видів діяльності знімуть перешкоди для формування i розвитку конкурентного ринку залізничних перевезень (рис.1).

Обов'язковими завданнями держави щодо залізничної галузі мають бути такі:

1) створення правового, організаційного, економічного підгрунтя фінансово-інвестиційного забезпечення розвитку;

2)

регулювання питань реформування, що відповідало б сучасним умовам функціонування, міжнародним вимогам, захисту національних інтересів;

3) підтримка національного виробника тягового та рухомого складу, фінансування інвестиційних проектів за рахунок держбюджету (держзамовлення);

4) удосконалення нормативноправової бази діяльності;
5) здійснення та контроль виконання заходів екологічної політики;

6) підтримка i розвиток інноваційного сектора економіки; стимулююча політика інновацій;

7) розвиток вітчизняної мережі міжнародних транспортних коридорів та їх інфраструктури тощо.

Необхідність посилення регулюючої та підтримуючої функції держави щодо розвитку залізничної галузі дозволило удосконалити принципи державної політики в цій сфері, серед яких:

1) першочерговість національних інтересів при визначені заходів розвитку в результаті взаємодії 3 міжнародними транспортними організаціями;

2) відповідність та взаємодоповнюваність заходів державної промислової, транспортної, інвестиційної, соціальної та інших політик загальній меті - забезпечення конкурентоспроможності національної залізничної транспортної системи;

3) обов'язковість виконання зобов'язань, що визначені в державних програмах та стратегіях розвитку;

4) прогнозованість заходів державного регулювання.

Враховуючи розвиток нових механізмів державного управління залізничною галуззю, які були досліджено, визначено основні цілі державного управління залізничною галуззю та можливі результати їх впровадження, що дозволило узагальнити напрямки удосконалення механізму державного управління розвитком залізничної галузі, які забезпечать: затвердження відповідної ефективної законодавчої бази, повне відокремлення функцій державного регулювання від господарських функцій, впровадження нової системи державного регулювання тарифів, новий підхід до організації перевезень пасажирів, впровадження системи державного управління у сфері безпеки європейського зразка (рис. 2). 


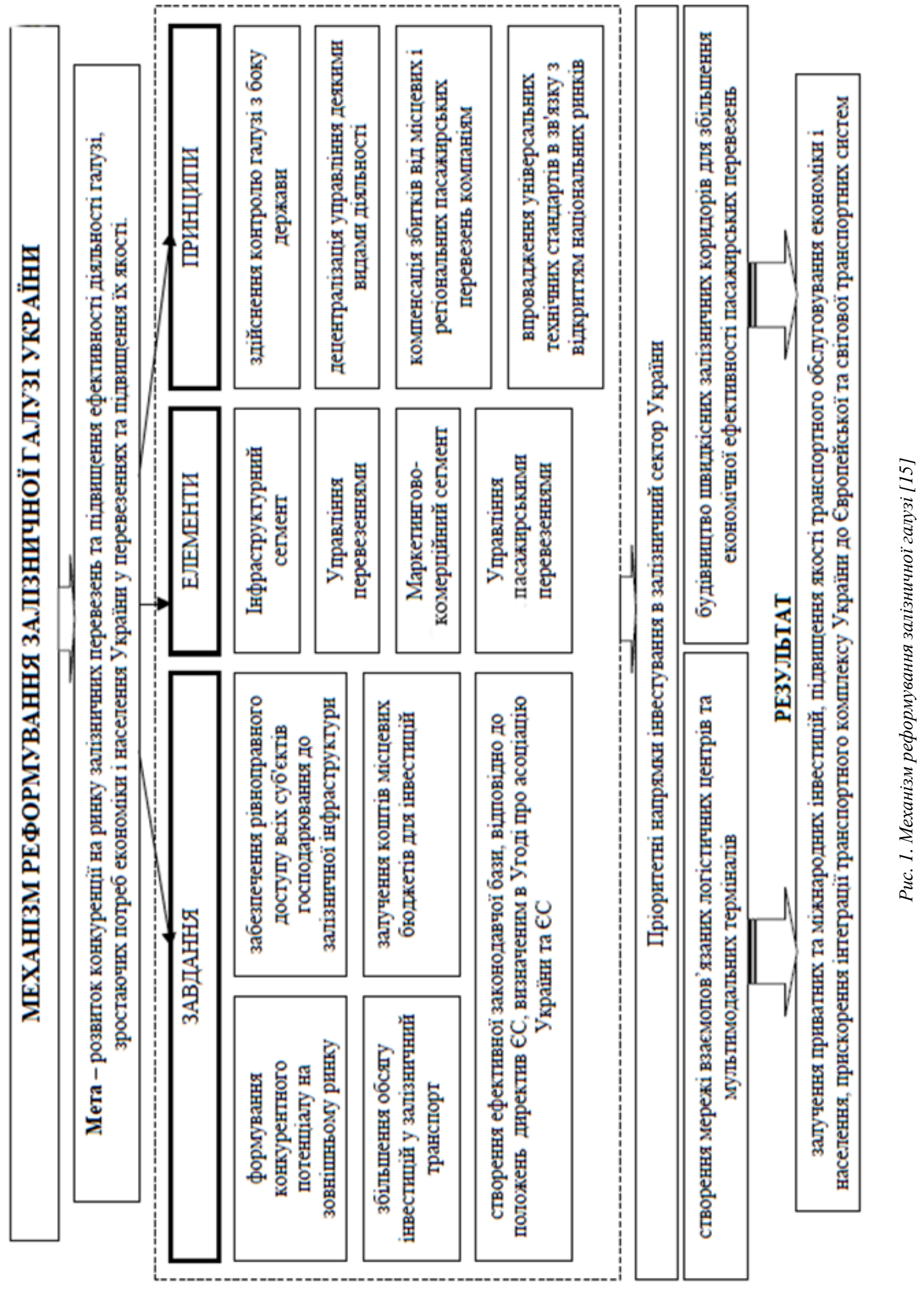




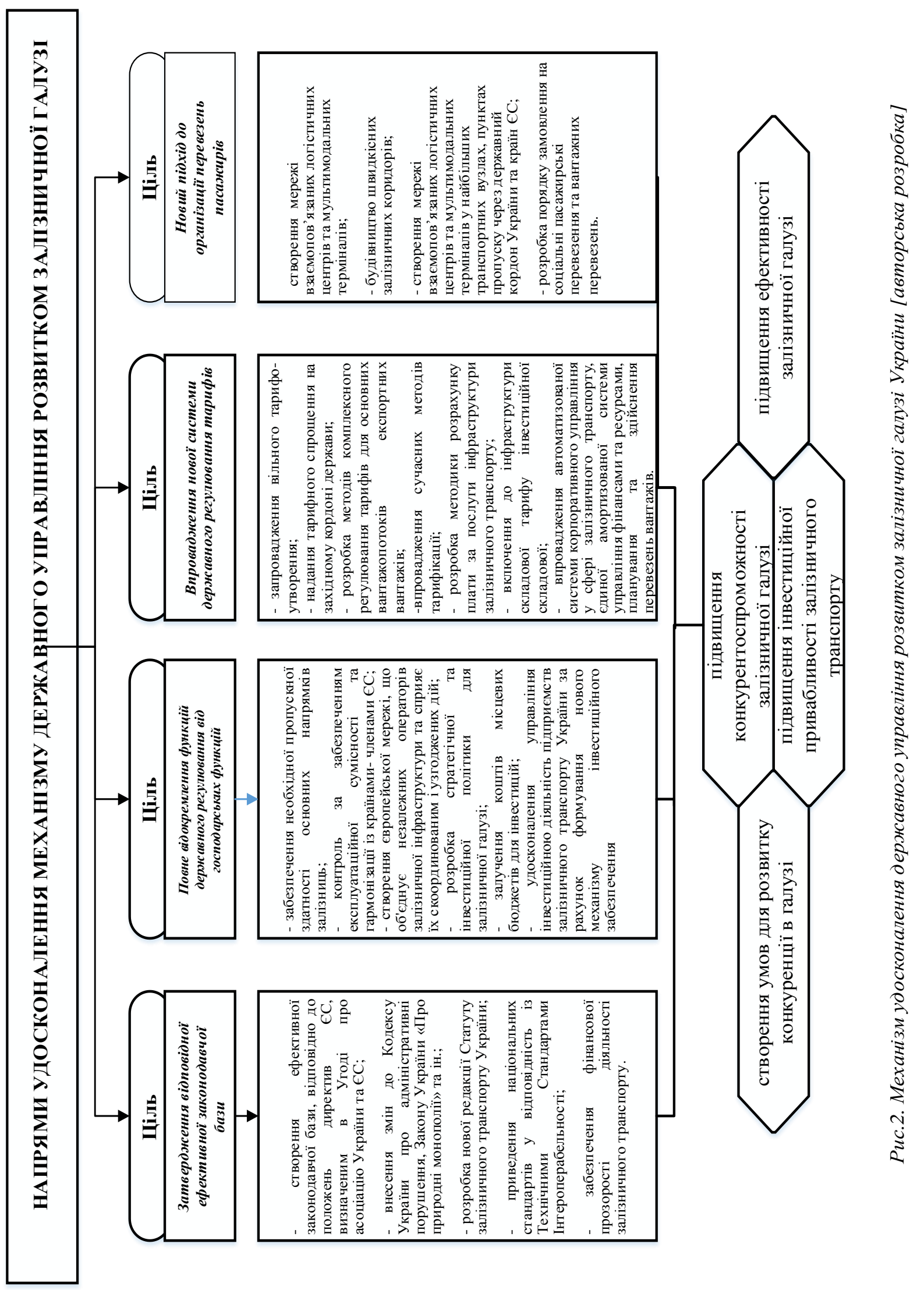


У результаті розмежування державних i господарських функцій, розподілу монопольних та конкурентних видів діяльності будуть зняті перешкоди для розвитку конкурентного ринку залізничних перевезень, на якому будуть працювати нові підприємства вантажних i пасажирських перевезень різних форм власності та допоміжні підприємства залізничного транспорту.

\section{Удосконалення}

державного

управління залізничної галузі відкриє нові можливості 3 формування додаткових власних джерел інвестицій за рахунок реструктуризації активів. Підвищиться інвестиційна привабливість національних залізниць для приватного та іноземного капіталу.

У результаті виникне можливість прискорити техніко-технологічну модернізацію залізничного транспорту на рівні європейських і світових стандартів, що буде сприяти: максимальній реалізації транзитного потенціалу України; прискоренню

темпів

євроінтеграції.

Проведення цих заходів крім підвищення галузевої ефективності, дозволить отримати

загальноекономічний ефект за рахунок стимулювання розвитку транспортного машинобудування, експорту транспортних послуг за європейськими стандартами.

Висновок. Сучасна державна політика в сфері регулювання залізничної галузі потребує реформування відповідно до норм Свропейського Союзу в умовах розвитку інтеграційних процесів. У зв'язку 3 зазначеним обгрунтовано необхідність удосконалення системи управління залізничним транспортом та забезпечення державної підтримки його реформування, що дозволить підвищити конкурентоспроможність українських залізниць на ринку транспортних послуг.

Формування державної політики розвитку залізничної галузі в умовах євроінтеграційного процесу дозволять вирішити наукову задачу щодо удосконалення механізму державного управління залізничної галузі України. За рахунок розширення організаційноекономічного та ресурсного інструментарію. Це дозволить підвищити конкурентоспроможність залізничної галузі України в умовах єврорегіонального співробітництва та інтеграції.

\section{ПЕРЕЛІК ВИКОРИСТАНИХ ДЖЕРЕЛ}

1 Кіндзерський

Ю.B.

Промисловість України: стратегія і політика структурно-технологічної модернізації / Ю.В. Кіндзерський. - Київ: НАН України, Ін-т екон. та прогнозування, 2013. - 536 с.

2 Кизим М.О. Промислова політика та кластерізація економіки України / М.О. Кизим. - Х.: «ІНЖЕК», 2011. - 304 c.

3 Ляшенко B.I. Перший етап модернізації економіки України: досвід та проблеми / B.I. Ляшенко. - Запоріжжя: ІЕП НАН України, 2014. - 798 с.

4 Шепетько P.I.

Неоіндустріалізація як фаза технологічного розвитку реального сектору економіки / P.I. Шепетько // Формування ринкових відносин в Україні. - 2014. - № 8. - С. 29-33.

5 Дикань В. Л. Державне регулювання промислового розвитку України / В. Л. Дикань, М. В. Корінь //Вісник економіки транспорту i промисловості. - 2018. - №. 61 .

6 Дикань В.Л. Сутнісні аспекти конкурентоспроможності національної економіки / В.Л. Дикань, О.Г. Кірдіна // Вісник економіки транспорту i промисловості. - 2009. - № 28. - С. 13-20.

7 Дикань В.Л. Механізм створення залізнично-транспортнопромислової групи в сучасних умовах розвитку залізничного транспорту України / В.Л. Дикань, М.В. Кондратюк // 
Вісник економіки транспорту i промисловості. - 2009. - № 26. - С. 13-18.

8 Якубовський М. Концептуальні основи стратегії розвитку промисловості України на період до 2017 року / M. Якубовський, В. Новицький, Ю. Кіндзерський // Економіка України. 2007. - № 11. - C. 4-19

9 Ейтутіс Г. Потенційні джерела інвестування в розвиток залізничного транспорту України: можливості їх диверсифікації / Г. Ейтутіс, О. Никифорук, О. Бойко // Економіст. - 2012. - №8. - С. 64-69.

10 Якименко Н. В. Методологічні основи державного регулювання розвитку залізничного транспорту України / Н. В. Якименко. // Вісник економіки транспорту і промисловості. - 2010. - №31. - С. 197202.

\section{1 Бараш Ю.С.} залізничним транспортом країни: 2-е управління в умовах системних змін. Серія: вид.,перероб. і доп / Ю.С. Бараш. - Державне управління: зб. наук. пр. Дніпропетровськ.- 2006. - 259 с.

12 Кірдіна О.Г. Необхідність 297. - С.122-132. науково-виробничої інтеграції як форми реалізації інвестиційно-інноваційного проекту організації швидкісного рухузалізницями України / О. Г. Кірдіна // Вісник ХНАУ. -2010. - № 10. - С. 183-194.

13 Токмакова I.В. Дослідження сутності стійкого розвитку залізничного транспорту / I.B. Токмакова // Вісник економіки транспорту і промисловості. 2010. - №29. - C.227-229.

DOI 10.18664/338.47:338.45.v\%vi\%i.133507
14 Про затвердження Державної цільової програми реформування залізничного транспорту на 20102019 роки [Електронний ресурс] : Постанова Кабінету міністрів України від 16 грудня 2009 р. №1390 //Законодавство / Верховна Рада України. - Електрон. текст. дані. - Київ, 2012.

15 Щодо підвищення ефективності організаційно-економічного забезпечення єврорегіонального співробітництва України та $\epsilon$ : аналіт. записка [Електронний ресурс] / Національний інститут стратегічних досліджень. Електрон. дані. - Режим доступу: :http://www.niss.gov.ua/articles/1229/ (дата звернення: 22.12.2016). - Назва з екрана.

16 Матвієнко В.В. Державний реформування залізничної галузі: європейський досвід / В.В. 17 Толстова А.В. Роль державного регулювання в процесі детінізації економіки України / А.В. Толстова // Вісник економіки транспорту і промисловості Харків: УкрДАЗТ, 2012. - №40. - С. 303306.

18 Островерх Г. Є. Tеорії управління розвитком залізничного транспорту / Г. С. Островерх // Вісник економіки транспорту і промисловості. 2017. - №. 59. - С. 235-242 